\title{
Seepage Behavior of Earth Dams Considering Rainfall Effects
}

\author{
Jong-Wook Lee, ${ }^{1}$ Jiseong Kim, ${ }^{2}$ and Gi-Chun Kang $\mathbb{D D}^{3}$ \\ ${ }^{1}$ Infrastructure Research Center, K-Water Institute, 200 Sintanjin-ro, Daedeok-gu, Daejeon 306-711, Republic of Korea \\ ${ }^{2}$ Department of Cadastre and Civil Engineering, Vision College of Jeonju, 235 Cheonjam-ro, Wansan-gu, \\ Jeonju, Jeollabuk-do 55069, Republic of Korea \\ ${ }^{3}$ Department of Civil Engineering, Engineering Research Institute, Gyeongsang National University, \\ 501 Jinjudero, Jinju, Gyeongsangnam-do 52828, Republic of Korea
}

Correspondence should be addressed to Gi-Chun Kang; gkang@gnu.ac.kr

Received 30 March 2018; Accepted 2 May 2018; Published 15 July 2018

Academic Editor: Hailing Kong

Copyright (๑) 2018 Jong-Wook Lee et al. This is an open access article distributed under the Creative Commons Attribution License, which permits unrestricted use, distribution, and reproduction in any medium, provided the original work is properly cited.

\begin{abstract}
More than $60 \%$ of annual rainfall in Korea is concentrated during the monsoon season from June to August because of the climate characteristics of East Asia. In general, reservoir water levels sharply rise during this period and rock-fill dams are exposed to various types of damages such as soil erosion and piping related to seepage problems. However, the detection of seepage problems is generally more difficult because rainfall directly flows into a V-notch weir according to a downstream shell in which seepage rates can be measured downstream. In this paper, rainfall is filtered out from the measured seepage rates to evaluate the effects of rainfall by using a digital filtering method for two large rock-fill dams (Dams A and B). Seepage behavior for these two large rockfill dams was estimated as a steady-state condition. It has been proven that with the application of a digital filter which filters out rainfall-induced infiltration into a downstream shell from a measured seepage flow would make analyzing the seepage behavior of dams more effective. This also shows that consideration for any rainfall effect on the seepage behavior of earth dams is very important. The seepage rate of Dam A was not significantly affected by rainfall because the seepage water was collected inside the dam body and was transferred to a V-notch weir located downstream from the dam through a steel pipe. On the contrary, the seepage rate of Dam B was greatly influenced by rainfall in the rainy season. Also, the permeability of the core zones for Dams A and $\mathrm{B}$ was estimated at $8.5 \times 10^{-5} \mathrm{~cm} / \mathrm{sec}$ and $2.7 \times 10^{-5} \mathrm{~cm} / \mathrm{sec}$, respectively, by a simplified method.
\end{abstract}

\section{Introduction}

The seepage through an earth dam or a rock-fill dam generally correlates with the reservoir water level of the dam. Abnormal seepage problems, such as piping in the core zone of the dam, can be detected by carefully analyzing the relationship between the reservoir water level and the seepage rate. According to the design standards of a dam in Korea [1], seepage barriers and V-notch weirs should be installed downstream from dams. The seepage rate through a dam should be measured and used as a basis of a seepage stability evaluation. Seepage barriers in various forms have been used to control seepage and to mitigate seepage problems in dams. Since the 1970s, rigid barriers consisting of unreinforced concrete, plastic concrete, deep-mixed soil cement, and jetted grout have been used extensively in new dam construction and for mitigation of seepage problems in existing dams [2, 3]. Seepage-induced piping is the most common cause of dam failures. In previous case studies, $46 \%$ of the failures of large dams can be attributed to piping [4-7]. ASTM [8] defines piping as the progressive removal of soil particles from a soil mass by percolating water, leading to the development of channels. Seepage erosion occurs when the water flowing through a crack or defect erodes the soil from the walls of the crack or defect [9-12]. Therefore, seepage monitoring is the most important approach to preventing damage due to seepage problems [13-15].

Seepage that flows out of a rock-fill dam is typically monitored at the downstream toe, and the measured seepage flow inevitably includes rainfall-induced infiltration into the downstream shell as well as reservoir-specific seepage through a core zone. Subsequently, the rainfall should be 
excluded from the seepage rate to increase the accuracy of the measurement. Additionally, base flow estimations can be used to investigate the effects of rainfall on the relationship between the seepage rate and the reservoir water levels. It has long been a topic of interest in hydrology because of its importance in understanding hydrologic processes, which play a crucial role in water resources management [16-18]. In recent years, it has increasingly been used as tracers to investigate groundwater-surface water interaction $[19,20]$ and a separate base flow from storm runoff or annual stream flows [21]. Figure 1 shows the components of the measured seepage flow out of a rock-fill dam considering the rainfall [18]. During the dry season, water stored in the dam is removed by soil water drainage. These processes proceed at different rates in time and space as well as not being readily quantified. The gradual depletion of discharge during periods with little or no precipitation constitutes the drainage or recession rate, which can be graphically presented as the recession curve [18].

To carry out dam safety analysis based on relationships between reservoir-specific seepage and reservoir water levels, the seepage flow measured at a V-notch weir of the downstream toe is adjusted to filter out rainfall-induced infiltration into the downstream shell. To address this problem, this study applied a method to filtering out rainfallinduced infiltration into the downstream shell by using digital filtering at two rock-fill dams in Korea. After which, the seepage behavior and permeability of the core zones were analyzed to determine the relationship between reservoir water levels and adjusted seepage flows. The hydraulic conductivities of the core zones were also inversely analyzed through a conventional seepage analysis.

\section{Digital Filtering for Calibrating Rainfall Effects}

2.1. Digital Filtering Process. Although there is an effort [22] to reduce the subjectivity associated with traditional graphical methods of base flow separation in hydrology, their application is restricted to well-defined, single-peaked, and isolated hydrographs [23]. However, the hydrographs measured in humid regions are generally continuous and consist of multiple peaks. In recent years, recursive digital filters have been developed and applied for base flow separations. The recursive digital filters are based on the principle used in signal processing by regarding the base flow and direct runoff as low- and high-frequency signals, respectively.

The digital filters provide an effective alternative to the graphical methods, as digital filters can be easily automated and are capable of providing reproducible results. Many researchers have proposed digital filters [24-28]. Tan et al. [29] compared the hydrograph separation characteristics between Nathan and McMahon [24] and Chapman and Maxwell [26] for a partially urbanized watershed. Nathan and McMahon's method which provided the more reliable separation result was adopted to separate the base flow from the total runoff hydrograph.

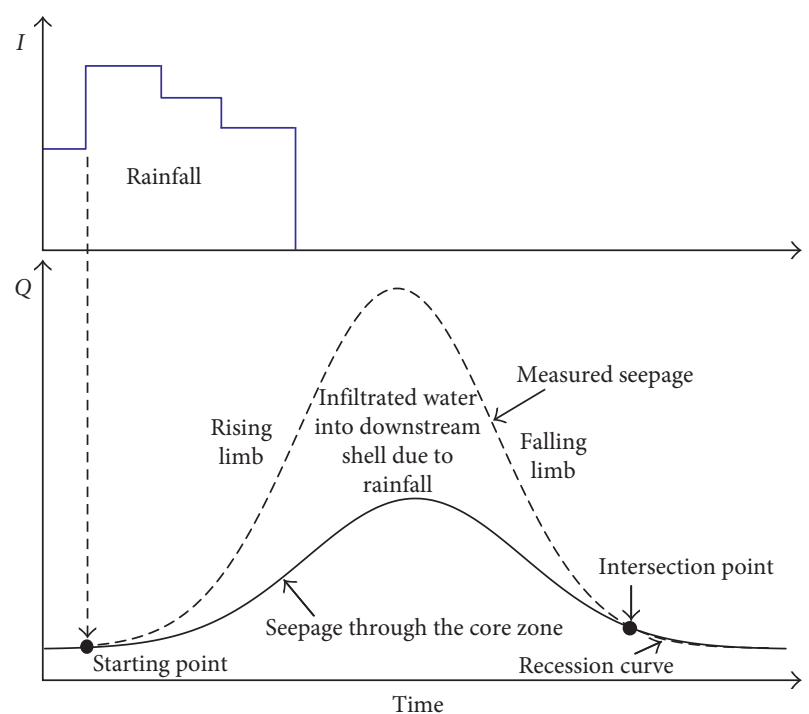

FIgURE 1: Components of seepage flow of rock-fill dams considering rainfall.

In this study, the digital filter proposed by Nathan and McMahon [24] was utilized for the separating of rainfallinduced infiltration from measured seepage through a rockfill dam. Mugo and Sharma [30] showed that the algorithm is capable of producing promising separation results for three humid tropical forested catchments with area from 0.36 to $0.65 \mathrm{~km}^{2}$.

$$
\begin{aligned}
& Q_{\mathrm{d}, i}=\beta_{\mathrm{d}} \cdot Q_{\mathrm{d}, i-1}+\frac{1+\beta_{\mathrm{d}}}{2}\left(Q_{i}-Q_{i-1}\right), \\
& Q_{\mathrm{b}, i}=\frac{1-k}{2}\left(Q_{i}+Q_{i-1}\right)+k \cdot Q_{\mathrm{b}, i-1},
\end{aligned}
$$

where $Q_{b}=$ base flow, $Q_{d}=$ direct runoff, $i=$ time interval, $k=$ recession constant during periods where there is no direct runoff, $\beta_{\mathrm{d}}=$ filter parameter $(=k), d=$ direct runoff filter parameter, and $Q=$ measured seepage.

2.2. Recession Constant. To filter out the measured hydrographs using a digital filter, the recession constant $k$ of the study site needs to be estimated. Base flow recession is represented as follows:

$$
Q_{t}=Q_{0} e^{-t / \tau}=Q_{0} e^{-\alpha t}=Q_{0} k^{t} .
$$

where $Q_{0}$ and $Q_{t}=$ base flows at time 0 and $t$ and $\tau=$ turnover time of the groundwater storage, during a period when there is no recharge. In the following equation, a linear relationship between the groundwater discharge and groundwater storage, $S$, was assumed as follows:

$$
Q=\alpha S \text {. }
$$

Taking the natural log on both sides of (4) yields

$$
\ln Q_{t}=\ln Q_{0}=-\alpha t .
$$

The traditional approach which uses the semilogarithmic plot of a single recession segment is widely applied in 


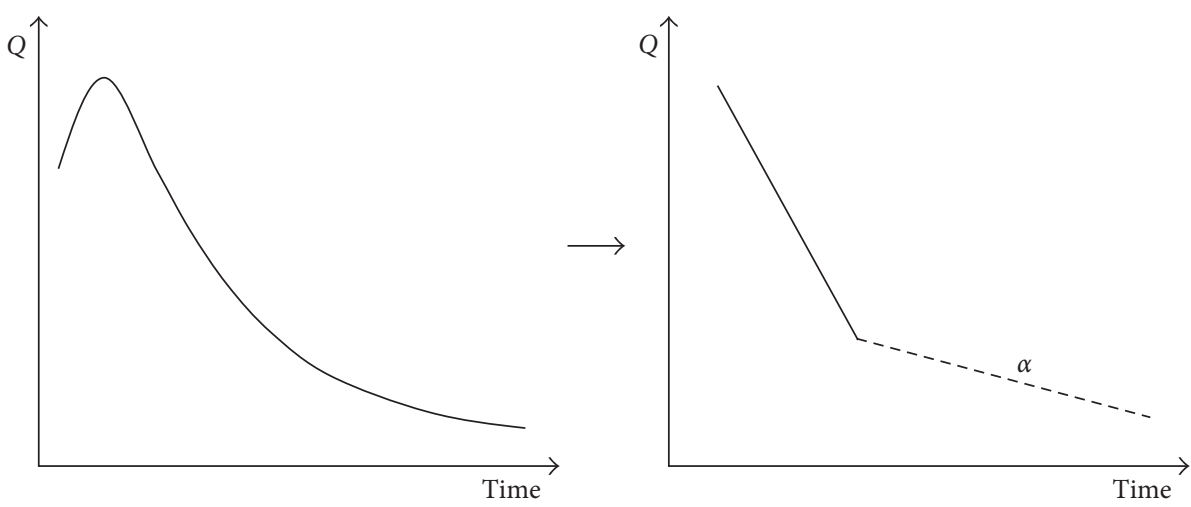

FIgURE 2: Determination of $\alpha$.

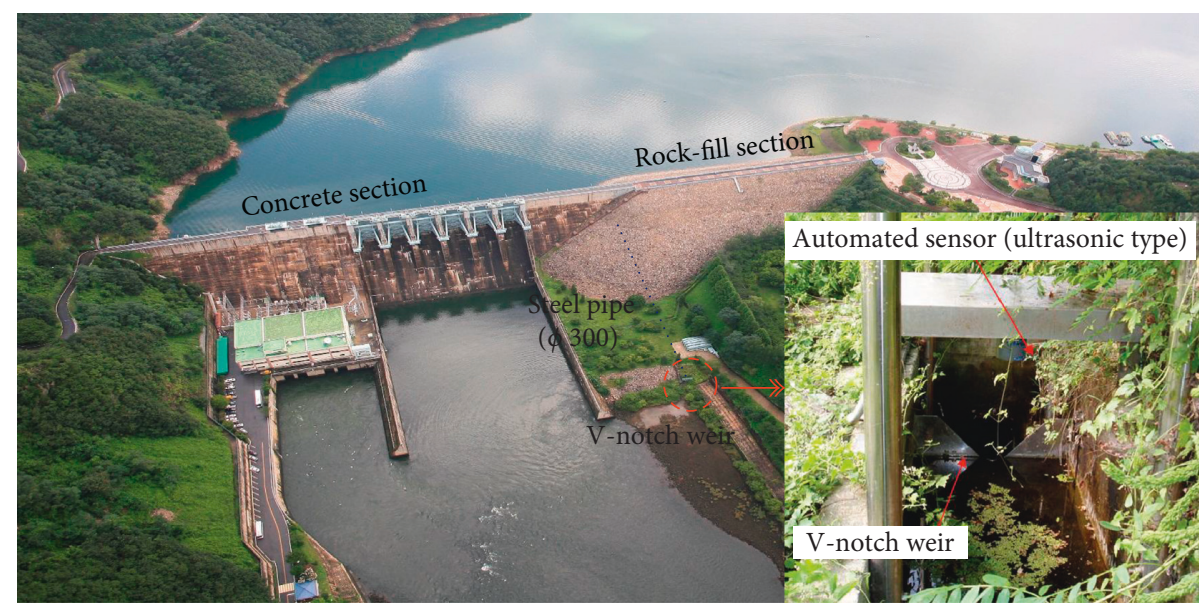

FIgURE 3: Aerial photo and seepage flow monitoring for Dam A.

estimating the recession constant. This approach plots the natural log of the measured runoff according to elapsed time and takes $\alpha$ as the minimum slope corresponding to the base flow portion of the hydrograph (i.e., the linear portion of the $\ln Q_{\mathrm{t}}$ plot). Vogel and Kroll [31] found that the traditional approach is able to provide a reliable $\alpha$ estimate by averaging the recession constant values obtained from an ensemble of individual hydrograph recessions. Sujono et al. [32] found that the semilogarithmic approach produces reasonable and comparable estimates with those obtained from more complicated methods such as the master recession curve method [24] and the wavelet transform method [33, 34]. As shown in Figure 2, once the $\alpha$ value is determined, the recession constant, $k$, can then be estimated as follows [35]:

$$
k=e^{-\alpha} \text {. }
$$

\section{Seepage Flow Monitoring}

In this study, the relationships among rainfall, water level, and seepage measured from two rock-fill dams (Dam A and Dam B) were investigated. Dam A is a hybrid-type dam combined with a concrete section on the right side and a rock-fill section on the left side as shown in Figure 3. The dam is $53 \mathrm{~m}$ height and $496 \mathrm{~m}$ length in total, and the
TABLE 1: Summary of investigated dams.

\begin{tabular}{|c|c|c|c|}
\hline & \multicolumn{2}{|c|}{ Dam A } & Dam B \\
\hline Completion year & \multicolumn{2}{|c|}{1981} & 1992 \\
\hline Height (m) & \multicolumn{2}{|c|}{53.0} & 58.0 \\
\hline Length of crest (m) & $\begin{array}{c}\text { Total } \\
\text { Rock-fill }\end{array}$ & $\begin{array}{l}496.0 \\
131.6\end{array}$ & 330.0 \\
\hline Crest level (EL. m) & \multicolumn{2}{|c|}{83.0} & 115.0 \\
\hline Flood water level (EL. m) & \multicolumn{2}{|c|}{80.0} & 110.5 \\
\hline Normal high water level (EL. m) & \multicolumn{2}{|c|}{76.5} & 108.5 \\
\hline Low water level (EL. m) & \multicolumn{2}{|c|}{60.0} & 85.0 \\
\hline Foundation level (EL. m) & \multicolumn{2}{|c|}{31.0} & 56.5 \\
\hline
\end{tabular}

rock-fill section is $131.6 \mathrm{~m}$ long. The general information of the dam is given in Table 1 .

3.1. Dam A. The seepage monitoring device was installed downstream from the dam as shown in Figure 3. The collected seepage water behind the core zone is transported by steel pipe (300 $\mathrm{mm}$ diameter) to a seepage monitoring device. It consists of a $\mathrm{V}$-notch weir and an ultrasonic-type sensor to measure the overflow height. The measured seepage flow of Dam A during 1981 to 1985 is shown in Figure 4. It indicates that the seepage flow is strongly in agreement with the reservoir water level and that there are 


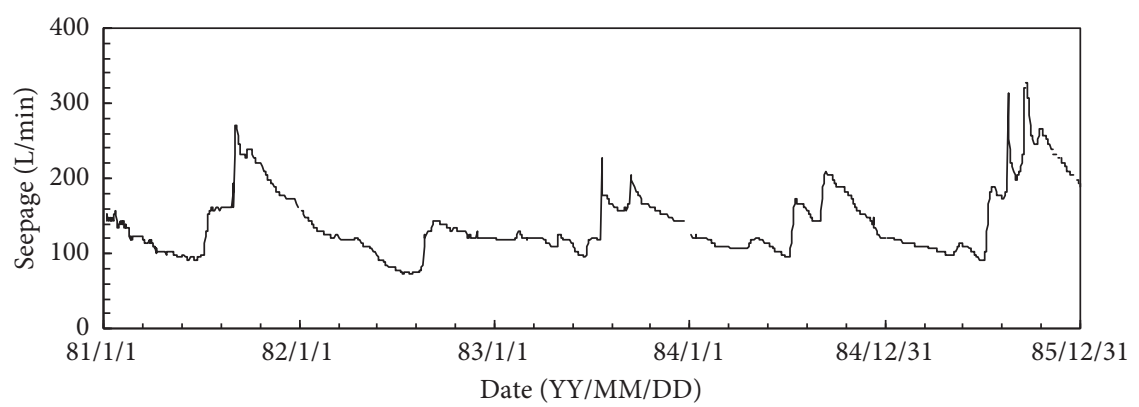

(a)

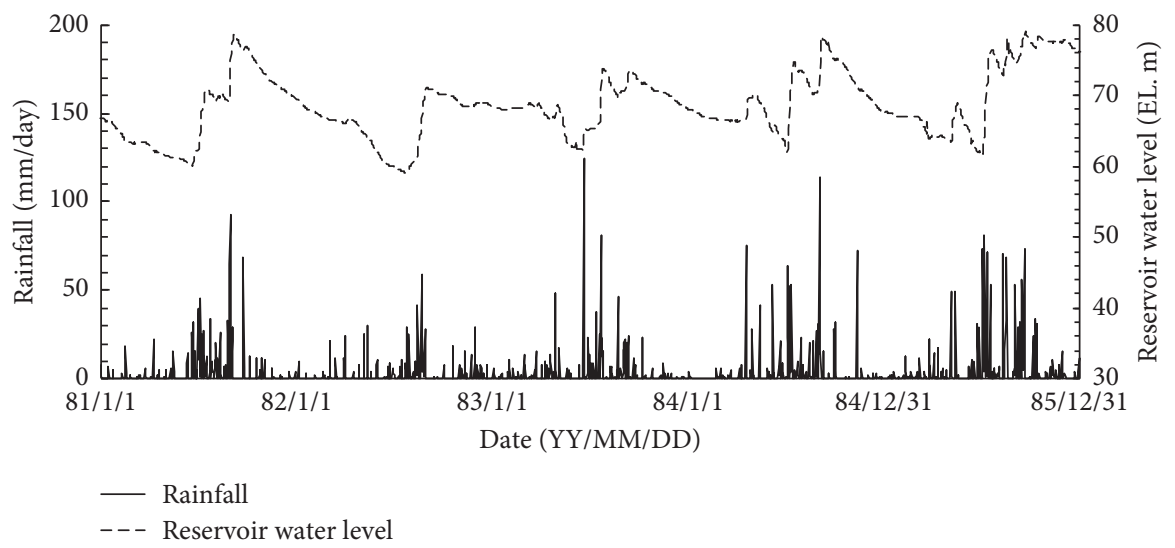

(b)

Figure 4: Time histories of (a) rainfall and reservoir water level and (b) measured seepage flow of Dam A.

no effects due to rainfall. The maximum seepage flow is $328 \mathrm{l} / \mathrm{min}$ at the reservoir water level $78.8 \mathrm{~m}$ which is more than normal high water levels $(76.5 \mathrm{~m})$ and less than flood water level $(80.0 \mathrm{~m})$.

3.2. Dam B. Dam B is a rock-fill dam with a central core. It is $58 \mathrm{~m}$ in height and $330 \mathrm{~m}$ in crest length. The general information of the dam is given in Table 1. The seepage monitoring device for Dam B was also installed downstream from the dam as shown in Figure 5. It consists of a V-notch weir and an ultrasonic-type sensor to measure the overflow height. Dam B has a problem with direct runoff due to rainfall flowing into the seepage monitoring system through the downstream of the rock-filled zone. Figure 6 shows the measured seepage flow from 2002 to 2007. The seepage followed the reservoir water level during the dry season, but it increased sharply during the wet season (June to September). The maximum seepage flow is $2,465 \mathrm{l} / \mathrm{min}$ with a reservoir water level of $103.7 \mathrm{~m}$. In this case, it is difficult to know the seepage flow through the core zone.

\section{Analysis of Monitoring Results}

4.1. Determination of Recession Constant. Two cases which include the big rainfall events were selected to determinate recession constant, $\alpha$, for Dam A during the study period. Figure 7(a) shows an event on August 29, 1981, in which the rainfall and seepage rate were recorded at $93.3 \mathrm{~mm} /$ day and at $193 \mathrm{l} / \mathrm{min}$, respectively. Figure 7 (b) shows an event on

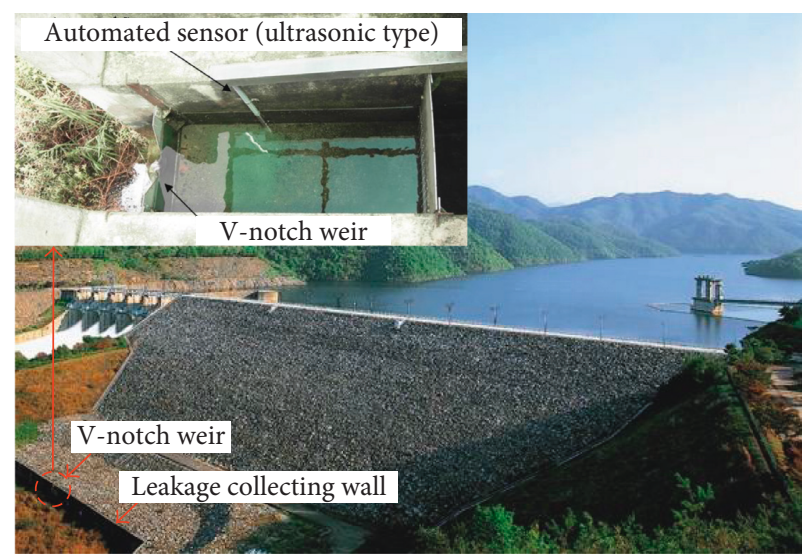

Figure 5: Aerial photo and seepage flow monitoring for Dam B.

August 17, 1985, in which the rainfall and seepage rate were recorded at $69 \mathrm{~mm} /$ day and at $313 \mathrm{l} / \mathrm{min}$, respectively. Even if the rainfall of the event in 1981 was larger than that in 1985 , the seepage rate of the 1981 event was smaller than that of the 1985 event. The reason for this discrepancy was that the reservoir water level in the event of 1985 (78.06 EL. m) was larger than that of 1981 (74.98 EL. m). According to the digital filter [24], the recession constant $k=0.843$ is determined as summarized in Table 2.

In the case of Dam B, rainfall events of twelves cases were selected to filter out rainfall-induced infiltration into the downstream shell. Figure 8 shows representative seepage 


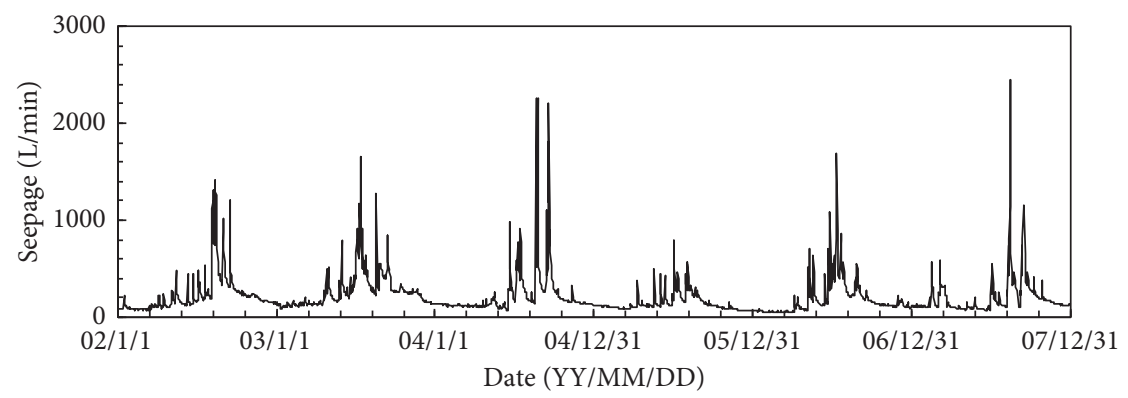

(a)

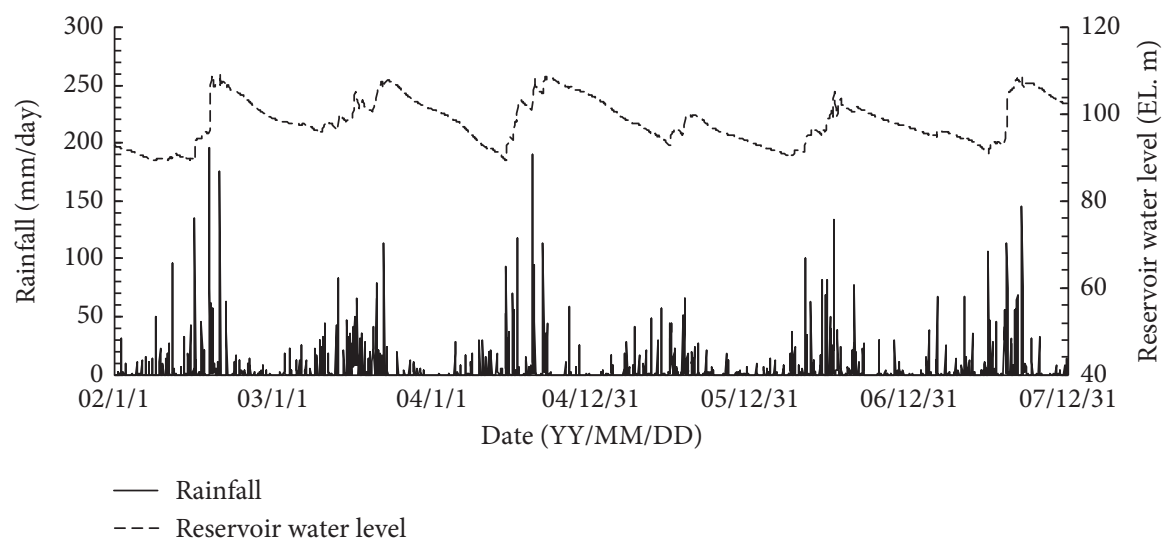

(b)

Figure 6: Time histories of (a) rainfall and reservoir water level and (b) measured seepage flow of Dam B.
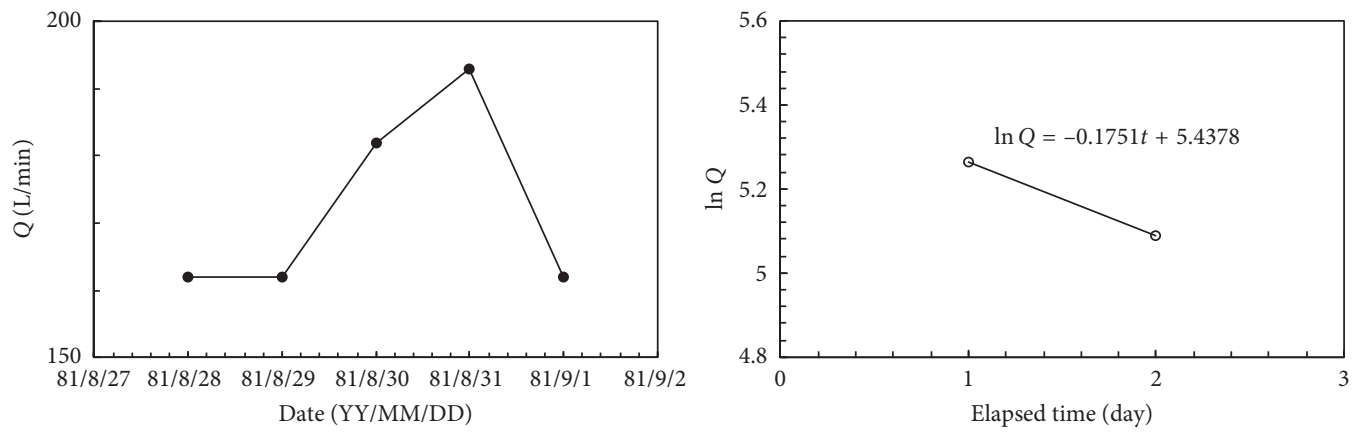

(a)
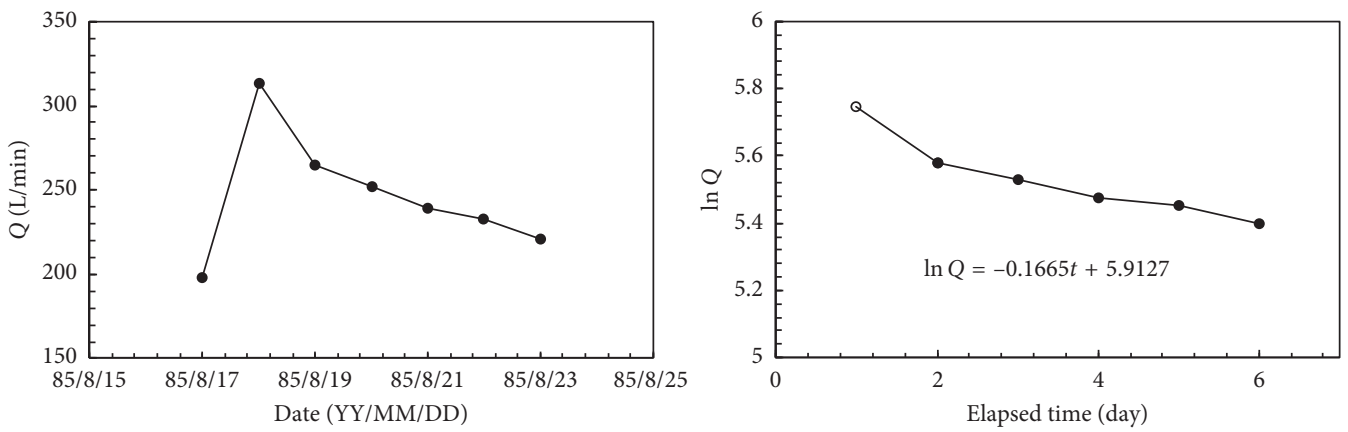

(b)

Figure 7: Measured seepage rate and determined $\alpha$ for Dam A. Event on (a) August 29, 1981, and (b) August $17,1985$. 
TABle 2: Recession constant values of Dam A.

\begin{tabular}{lccc}
\hline Event date & $\alpha$ & $k=e^{-\alpha}$ \\
\hline $1981-08-29$ & 0.1751 & 0.8394 \\
$1985-08-17$ & 0.1665 & 0.8466 \\
Average & - & 0.8430 \\
\hline
\end{tabular}
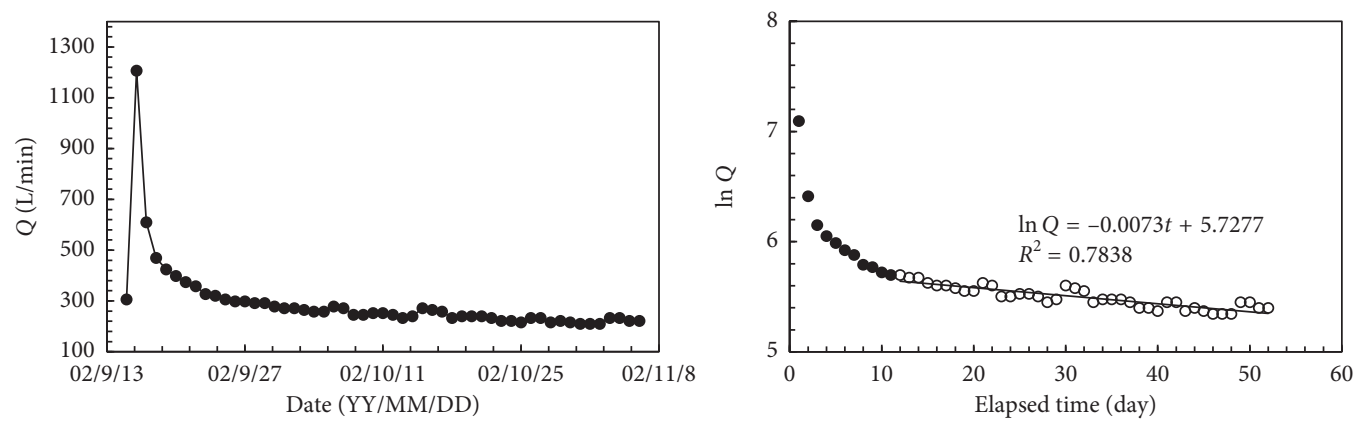

(a)
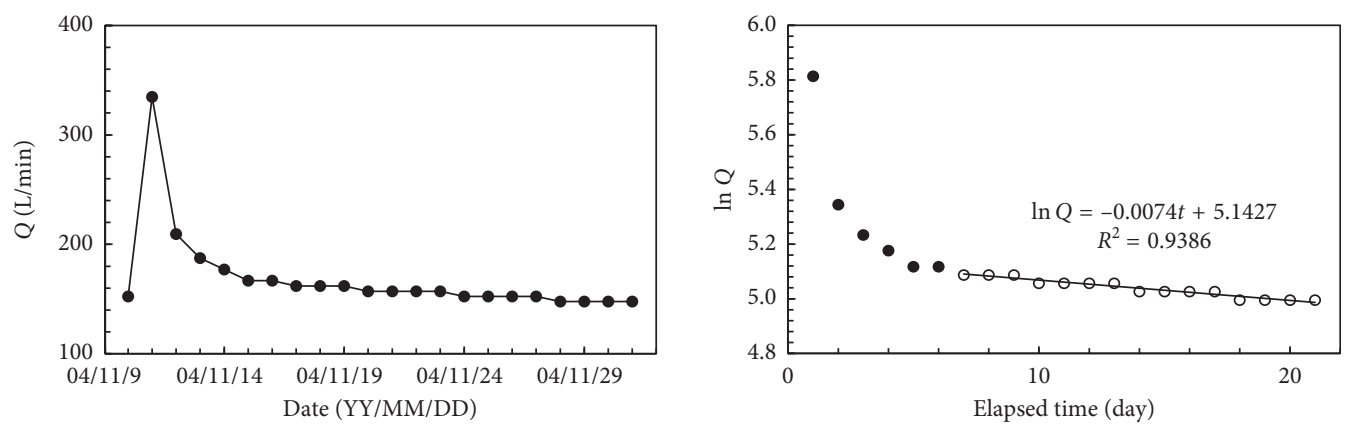

(b)
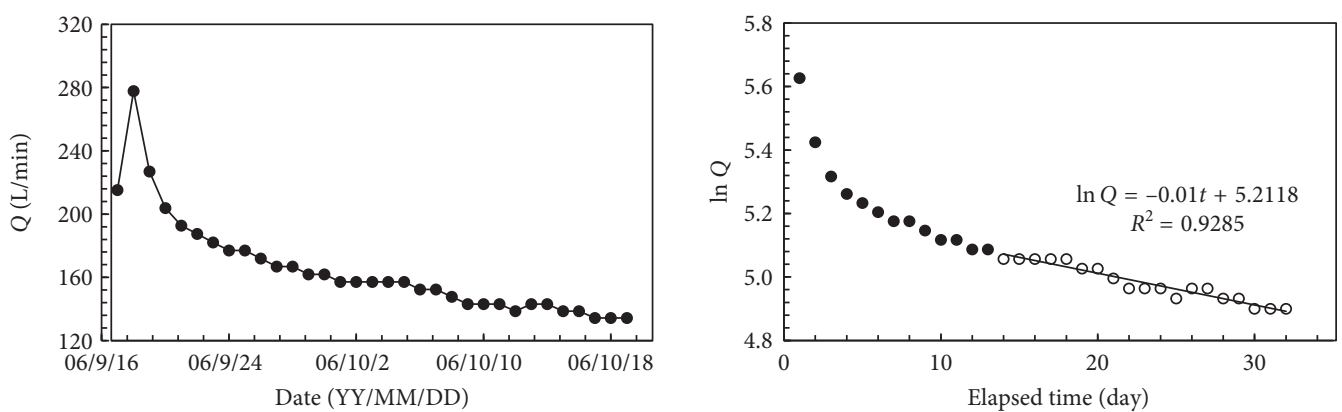

(c)
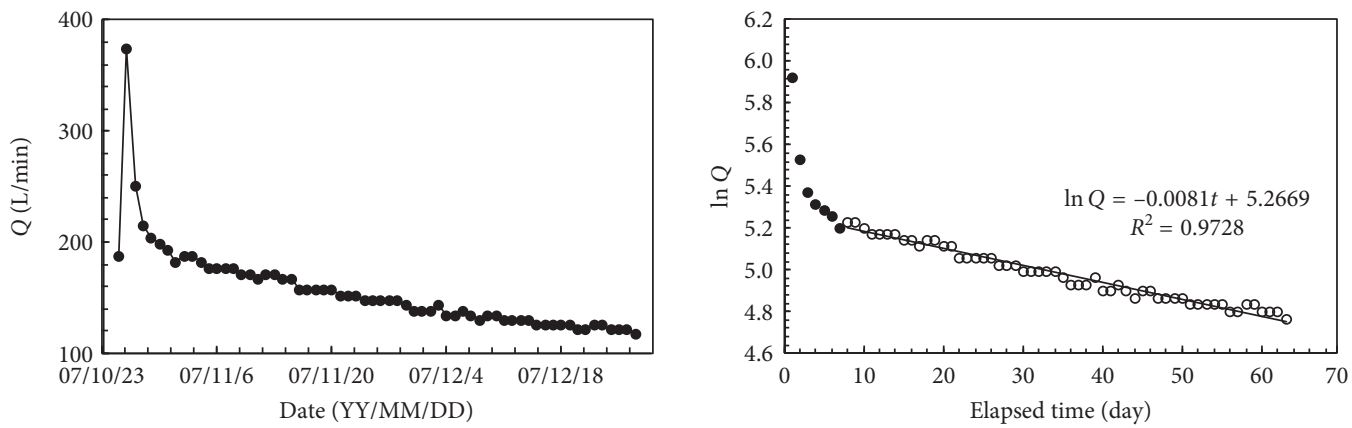

(d)

Figure 8: Representative measured seepage rate and determined $\alpha$ for Dam B. Event on (a) September 15, 2002, (b) November 10, 2004, (c) November 17, 2006, and (d) October 25, 2007. 
rate-time curves. As shown in Figure 8(a), the seepage rate of $1,206 \mathrm{l} / \mathrm{min}$ was recorded when rainfall was $63.4 \mathrm{~mm} /$ day and the reservoir water level was $106.1 \mathrm{EL}$. m. On the contrary, in the case of October 25th, 2007, a seepage rate of $188 \mathrm{l} / \mathrm{min}$ with a rainfall of $33.1 \mathrm{~mm} /$ day occurred even though the reservoir water level was almost the same (106.1 EL. m). This indicates that Dam B was largely affected by the rainfall into seepage rate compared to Dam A. The recession constant was estimated for each event as shown in Figure 8 and Table 3. It was then determined that $k=0.9925$.

4.2. Calibrating Seepage Flow. The measured seepage flows of Dams A and B were adjusted against rainfall-induced infiltration using (1) and (2) proposed by Nathan and McMahon [24]. Figure 9 shows the comparisons between the measured and adjusted seepage flows for Dam A. The results are strongly in good agreement which indicates that the rainfall effects are very minor and the seepage flow that occurred through the core zone was also found to be correlated with reservoir water level. On the contrary, the comparisons of Dam B in Figure 10 show that the measured seepage flows were filtered out and the peak values were removed by the digital filters. This indicates that the seepage flow of Dam B was strongly affected by rainfall. Although the maximum measured seepage of Dam B was 2,455 l/min on August 14, 2007, the adjusted seepage rate was $152.5 \mathrm{l} / \mathrm{min}$ when rainfall effect was excluded at the same period.

4.3. Prediction of Permeability. Chapuis and Aubertin [36] had studied seepage through various earth dams with the heights of 5, 10, 20, and $50 \mathrm{~m}$ under steady-state conditions. These studies have been numerically analyzed with a twodimensional finite element method, and they suggested a simplified method to predict the seepage flow rate as follows:

$$
\begin{aligned}
& \frac{Q}{k}=\alpha_{1}+\frac{\alpha_{2} \Delta h^{2}}{L}+\alpha_{3}\left(\frac{\Delta h^{2}}{L}\right)^{2}, \\
& L=0.5\left(L_{\max }+L_{\min }\right),
\end{aligned}
$$

where $Q=$ total seepage flow rate, $k=$ permeability of core zone, $\Delta h=$ the total head difference between the pond (constant head reservoir) and the toe of the downstream draining-filtering blanket, $L_{\max }=$ the core width (horizontally measured) at the bottom elevation of the downstream draining-filtering blanket and corresponds to the largest core width, $L_{\min }=$ the core width (horizontally measured) at the elevation of the pond surface and corresponds to the smallest core width below the pond surface, and $\alpha_{1} \sim \alpha_{3}$ are constant coefficients.

The values of parameters $\alpha_{1}$ and $\alpha_{2}$ depend on the range of $\Delta h^{2} / L$ as shown in Table 4 . Therefore, the predictive equation (7) and $\alpha_{1} \sim \alpha_{2}$ values in Table 4 were used to estimate permeability of core zones for Dams A and B.

Figure 11 shows the relationship between seepage flow and reservoir water level for Dam A. The permeability of the core zone for Dam A was calculated from (7). As shown in
TABLE 3: Recession constant values of Dam B.

\begin{tabular}{lcc}
\hline Event date & $\alpha$ & $k=e^{-\alpha}$ \\
\hline $2002-09-15$ & 0.0073 & 0.9927 \\
$2004-11-10$ & 0.0074 & 0.9926 \\
$2005-04-18$ & 0.0128 & 0.9873 \\
$2005-09-19$ & 0.0096 & 0.9904 \\
$2005-11-05$ & 0.0048 & 0.9952 \\
$2006-11-17$ & 0.0100 & 0.9900 \\
$2007-05-23$ & 0.0102 & 0.9899 \\
$2007-10-25$ & 0.0081 & 0.9919 \\
$2008-01-11$ & 0.0039 & 0.9961 \\
$2008-08-12$ & 0.0012 & 0.9988 \\
Average & - & 0.9925 \\
\hline
\end{tabular}

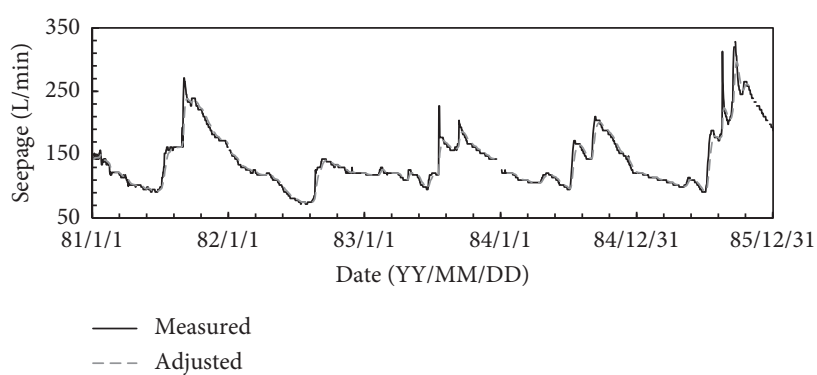

FIgURE 9: Comparisons between measured and calibrated seepage flow rate for Dam A.

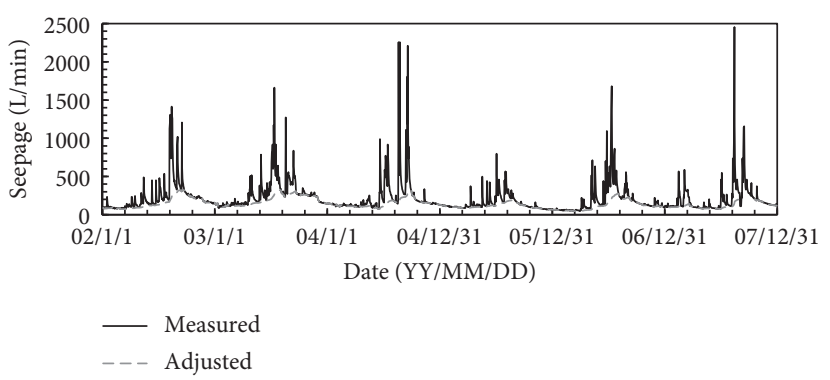

FIGURE 10: Comparisons between measured and calibrated seepage flow rate for Dam $B$.

Figure 11, it was estimated at $8.5 \times 10^{-5} \mathrm{~cm} / \mathrm{sec}$ and the watertightness of the core zone is judged to be fully secured so that they may serve as a seepage barrier. The relationship between seepage flow and reservoir water level for Dam B is shown in Figure 12. In the case of Dam B, adjusted seepage flow conducted in this study was used for predicting permeability of a core zone because seepage flow of Dam B was largely affected by rainfall and the permeability of the core zone was predicted as $2.7 \times 10^{-5} \mathrm{~cm} / \mathrm{sec}$. It indicates that the core zone is also judged to be fully secured.

\section{Conclusions}

In this study, a method to filter out rainfall-induced infiltration into the downstream shell using a digital filtering method was applied to two rock-fill dams. The seepage 
TABLE 4: Parameters $\alpha_{1}$ and $\alpha_{2}$ for a rock-fill dam with core zone as a function of $\Delta h^{2} / L_{0}$ [36].

\begin{tabular}{lccc}
\hline Range of $\Delta h^{2} / L$ & $\alpha_{1}$ & $\alpha_{2}$ & $\alpha_{3}$ \\
\hline$<10$ & 0.191 & 0.480 & 0 \\
$10 \sim 45$ & 0.264 & 0.462 & 0 \\
$45 \sim 180$ & 0.450 & 0.447 & 0 \\
\hline
\end{tabular}

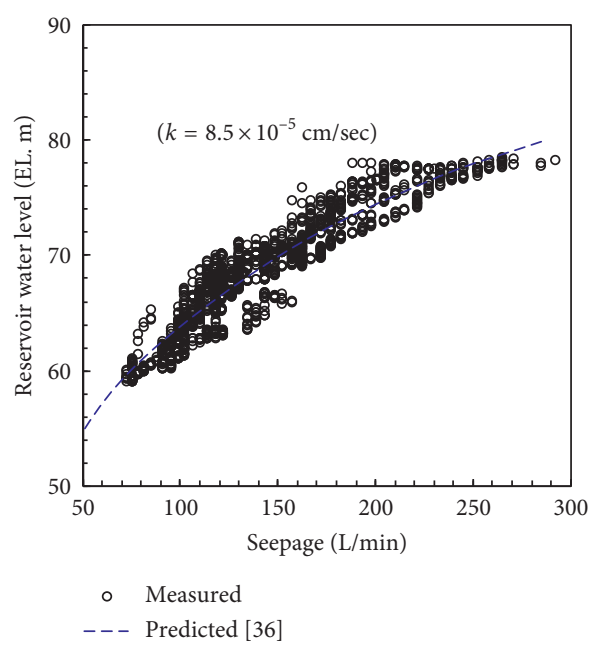

FIgURE 11: Predicted permeability of the core zone for Dam A.

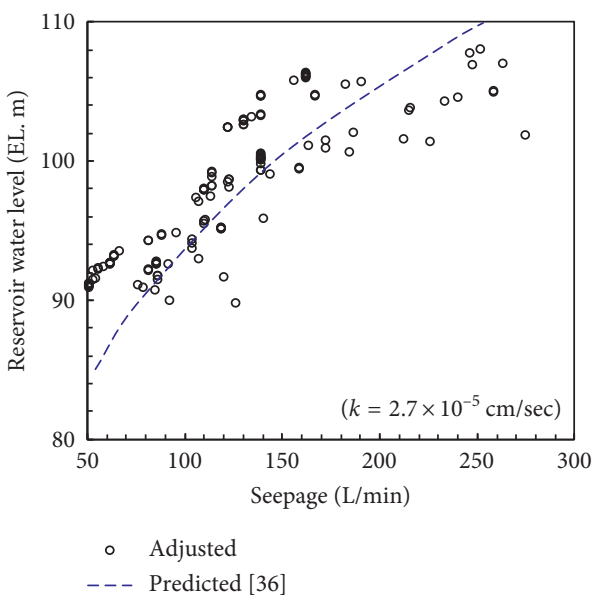

Figure 12: Predicted permeability of the core zone for Dam B.

behavior and watertightness of the core zones were analyzed by determining relationships between reservoir water level and adjusted seepage flow. Moreover, the permeability of the core zones for each dam was predicted through the conventional seepage analysis [36]. The following shows the summary of the consequent findings.

The differences between measured and adjusted seepage flow of Dam A was very small, and the effect of rainfall was found to be very minor. The seepage flow of Dam B was strongly affected by rainfall. The maximum measured seepage of Dam B was $2,455 \mathrm{l} / \mathrm{min}$, and the adjusted seepage was $152.5 \mathrm{l} / \mathrm{min}$ when the rainfall effect was excluded at the same date.
From the comparisons with measured and adjusted seepage flow, a digital filtering method to filter out rainfallinduced infiltration was used for the purpose of effectively analyzing the seepage behavior of dams.

The seepage flow through the core zones of Dams A and $\mathrm{B}$ was found to be correlated with the reservoir water level. This suggests that the seepage behavior of the core zone of both dams is in a stable state condition. Also, the permeability of the core zones for each dam was predicted as $8.5 \times 10^{-5} \mathrm{~cm} / \mathrm{sec}$ and $2.7 \times 10^{-5} \mathrm{~cm} / \mathrm{sec}$, respectively. Also, the watertightness of the core zone of both dams is judged to be fully secured and so they may serve as a seepage barrier.

Finally, a catchment for a dam should be constructed in the inner body of a dam such as in Dam A because this will exclude rainfall effects to improve the accuracy monitoring of seepage flow.

\section{Data Availability}

The data used to support the findings of this study are available from the corresponding author upon request.

\section{Conflicts of Interest}

The authors declare that they have no conflicts of interest.

\section{Acknowledgments}

This work was supported by the fund of Research Promotion Program, Gyeongsang National University, 2017. The authors acknowledge K-water for providing the valuable data.

\section{References}

[1] Korea Water Resources Association, Design Standard of Dams, Korea Water Resources Association, Seoul, Republic of Korea, 2005.

[2] J. D. Rice and M. Duncan, "Deformation and cracking of seepage barriers in dams due to changes in the pore pressure regime," Journal of Geotechnical and Geoenvironmental Engineering, vol. 136, no. 1, pp. 16-25, 2010.

[3] D. P. Stare, G. Filz, and D. A. Bruce, "The remediation of Buckeye Lake Dam, Ohio: deep mixing as an interim risk reduction measure and key component of final design," in Geotechnical Special Publication, (289 GSP), ASCE, pp. 395404, Reston, VA, USA, 2017.

[4] M. Foster, R. Fell, and M. Spannagle, "The statistics of embankment dam failures and accidents," Canadian Geotechnical Journal, vol. 37, no. 5, pp. 1000-1024, 2000.

[5] Y. Xu and L. Zhang, "Breaching parameters of earth and rockfill dams," Journal of Geotechnical and Geoenvironmental Engineering, vol. 135, no. 12, pp. 1957-1970, 2009.

[6] L. M. Zhang, Y. Xu, and J. S. Jia, "Analysis of earth dam failures-A database approach," Georisk, vol. 3, pp. 184-189, 2009.

[7] S. Chi, S. Ni, and Z. Liu, "Back analysis of the permeability coefficient of a high core Rockfill Dam based on a RBF neural network optimized using the PSO algorithm," Mathematical Problems in Engineering, vol. 2015, Article ID 124042, 15 pages, 2015. 
[8] American Society of Testing and Materials, Standard Terminology Relating to Soil, Rock, and Contained Fluids, ASTM, West Conshohocken, PA, USA, 2002.

[9] D. K. McCook, "A comprehensive discussion of piping and internal erosion failure mechanisms," in Proceedings of the 2004 Annual Association of State Dam Safety Officials, pp. 1-6, Phoenix, AZ, USA, September 2004.

[10] N. J. Jiang, K. Soga, and M. Kuo, "Microbially induced carbonate precipitation for seepage-induced internal erosion control in sand-clay mixtures," Journal of Geotechnical and Geoenvironmental Engineering, vol. 143, no. 3, article 04016100, 2017.

[11] L. Wang, Z. Chen, and H. Kong, “An experimental investigation for seepage-induced instability of confined broken mudstones with consideration of mass loss," Geofluids, vol. 2017, Article ID 3057910, 12 pages, 2017.

[12] Q. Lin, P. Cao, H. Wang, and R. Cao, "An experimental study on cracking behavior of precracked sandstone specimens under seepage pressure," Advances in Civil Engineering, vol. 2018, Article ID 4068918, 10 pages, 2018.

[13] J. Qiu, D. Zheng, and K. Zhu, "Seepage monitoring models study of earth-rock dams influenced by rainstorms," Mathematical Problems in Engineering, vol. 2016, Article ID 1656738, 11 pages, 2016.

[14] A. N. Alekseevich and A. A. Sergeevich, "Numerical modelling of tailings dam thermal-seepage regime considering phase transitions," Modelling and Simulation in Engineering, vol. 2017, Article ID 7245413, 10 pages, 2017.

[15] Z. Jiang and J. He, "Detection model for seepage behavior of earth dams based on data mining," Mathematical Problems in Engineering, vol. 2018, Article ID 8191802, 11 pages, 2018.

[16] B. F. Thomas, R. M. Vogel, and J. S. Famiglietti, "Objective hydrograph baseflow recession analysis," Journal of Hydrology, vol. 525, pp. 102-112, 2015.

[17] F. R. Hall, "Base flow recessions-a review," Water Resources Research, vol. 4, no. 5, pp. 973-983, 1968.

[18] L. M. Tallaksen, "A review of baseflow recession analysis," Journal of Hydrology, vol. 165, no. 1-4, pp. 349-370, 1995.

[19] P. A. Jaime and K. N. Oxtobee, "A field investigation of groundwater/surface water interaction in a fractured bedrock environment," Journal of Hydrology, vol. 269, no. 3-4, pp. 169-193, 2002.

[20] S. M. Wondzell, "Groundwater-surface-water interactions: perspectives on the development of the science over the last 20 years," Freshwater Science, vol. 34, no. 1, pp. 368-376, 2015.

[21] Y. K. Zhang and K. E. Schilling, "Increasing streamflow and baseflow in Mississippi River since the 1940s: effect of land use change," Journal of Hydrology, vol. 324, no. 1-4, pp. 412-422, 2006.

[22] J. Szilagyi and M. B. Parlange, "Baseflow separation based on analytical solutions of the Boussinesq equation," Journal of Hydrology, vol. 204, no. 1-4, pp. 251-260, 1998.

[23] V. T. Chow, D. Maidment, and L. W. Mays, "Applied hydrology," in Water Resources \& Environmental Engineering, McGraw Hill, New York, NY, USA, 1st edition, 1988.

[24] R. J. Nathan and T. A. McMahon, "Evaluation of automated techniques for base flow and recession analysis," Water Resources Research, vol. 26, no. 7, pp. 1465-1473, 1990.

[25] W. C. Boughton, "A hydrograph-based model for estimating the water yield of ungauged catchments," in Proceedings of the Hydrological and Water Resources Symposium, pp. 317-324, Institution of Engineers Australia, Newcastle, Australia, 1993.

[26] T. G. Chapman and A. I. Maxwell, "Baseflow separation comparison separation comparison of numerical methods with tracer experiments," in Proceedings of the Hydrological and Water Resources Symposium, pp. 539-545, Institution of Engineers, Hobart, Australia, 1996.

[27] T. G. Chapman, "A comparison of algorithms for stream flow recession and baseflow separation," Hydrological Processes, vol. 13, no. 5, pp. 701-714, 1999.

[28] K. Eckhardt, "How to construct recursive digital filters for baseflow separation," Hydrological Processes, vol. 19, no. 2, pp. 507-515, 2005.

[29] S. B. K. Tan, E. Y. Lo, E. B. Shuy, L. H. C. Chua, and W. H. Lim, "Hydrograph separation and development of empirical relationships using single-parameter digital filters," Journal of Hydrologic Engineering, vol. 14, no. 3, pp. 271-279, 2009.

[30] J. M. Mugo and T. C. Sharma, "Application of a conceptual method for separating runoff components in daily hydrographs in Kimakia Forest Catchments, Kenya," Hydrological Processes, vol. 13, no. 17, pp. 2931-2939, 1999.

[31] R. M. Vogel and C. N. Kroll, "Estimation of baseflow recession constants," Water Resources Management, vol. 10, no. 4, pp. 303-320, 1996.

[32] J. Sujono, S. Shikasho, and K. Hiramatsu, "A comparison of techniques for hydrograph recession analysis," Hydrological Processes, vol. 18, no. 3, pp. 403-413, 2004.

[33] A. Grossmann and J. Morlet, "Decomposition of Hardy functions into square integrable wavelets of constant shape," SIAM Journal of Mathematics, vol. 15, no. 4, pp. 732-736, 1984.

[34] G. A. Morlet, I. Fourgeau, and D. Giard, "Wave propagation and sampling theory," Geophysics, vol. 47, no. 2, pp. 203-236, 1982.

[35] L. Chen, H. Zheng, Y. D. Chen, and C. Liu, "Base-Flow separation in the source region of the Yellow River," Journal of Hydrological Engineering, vol. 13, no. 7, pp. 541-548, 2008.

[36] R. P. Chapuis and M. Aubertin, "A simplified method to estimate saturated and unsaturated seepage through dikes under steadystate conditions," Canadian Geotechnical Journal, vol. 38, no. 6, pp. 1321-1328, 2001. 


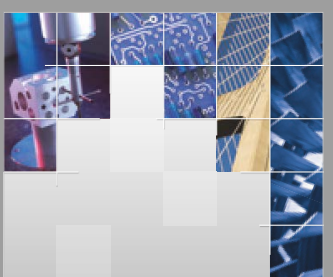

\section{Enfincering}
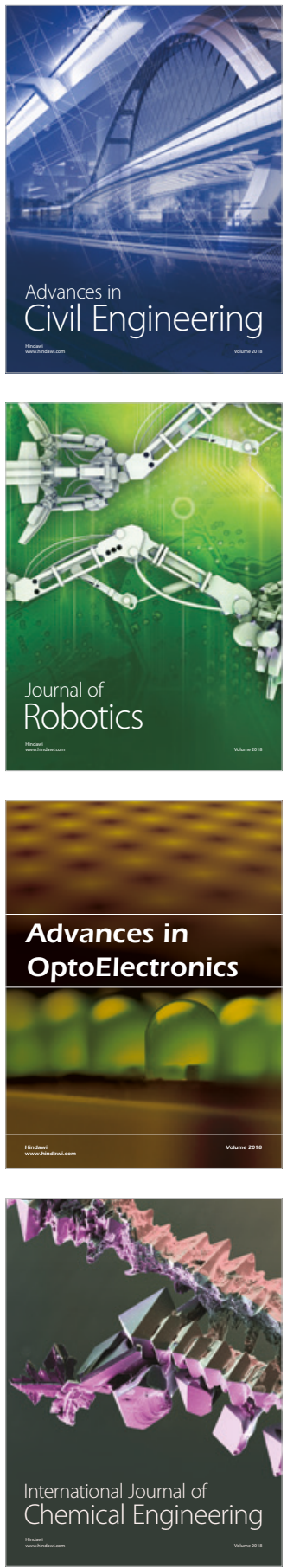

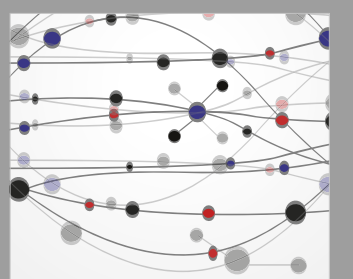

\section{Rotating \\ Machinery}

The Scientific World Journal

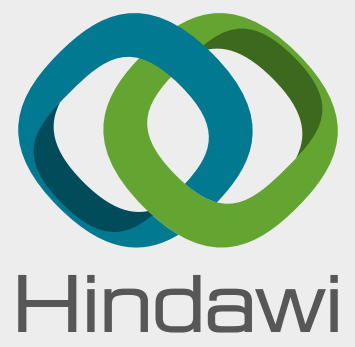

Submit your manuscripts at

www.hindawi.com
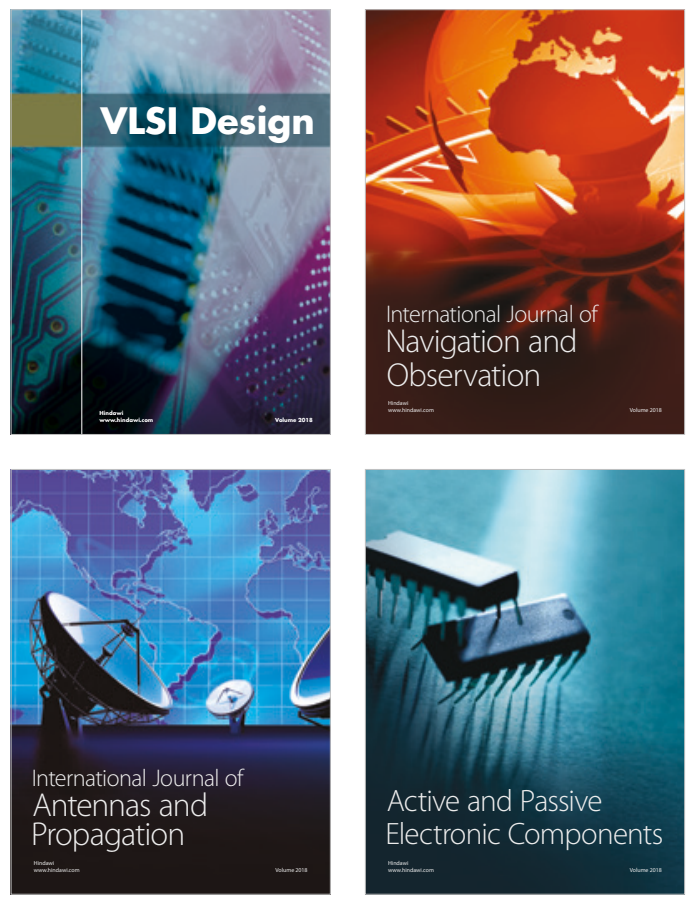
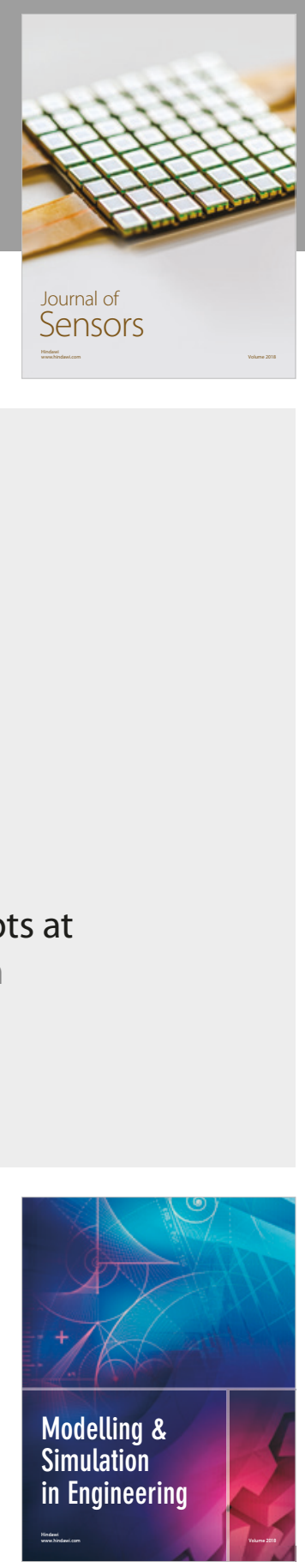

\section{Advances \\ Multimedia}
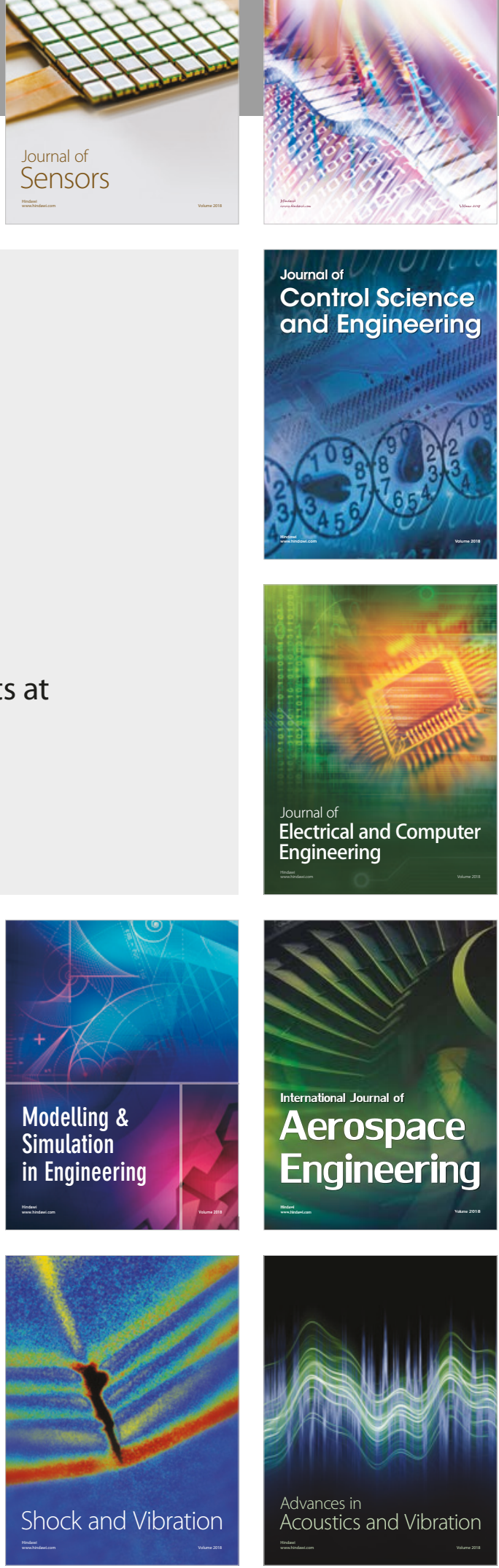